Jurnal Basicedu Volume 3 Nomor 4 Tahun 2019 Halaman 1082-1092

JURNAL BASICEDU

Research \& Learning in Elementary Education

https://jbasic.org/index.php/basicedu

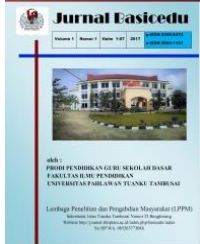

\title{
PENINGKATKAN KREATIVITAS DAN HASIL BELAJAR SISWA MELALUI MODEL PEMBELAJARAN PROJECT BASED LEARNING PADA SISWA SEKOLAH DASAR
}

\author{
Richard Adony Natty, ${ }^{1}$ Firosalia Kristin ${ }^{2}$, Indri Anugraheni ${ }^{3}$
}

Universitas Kristen Satya Wacana, Jawa Tengah, Indonesia ${ }^{1,2,3}$

Email :292014189@student.uksw.edu¹. firosalia.kristin@uksw.edu …indri.anugraheni@uksw.edu ${ }^{3}$

\begin{abstract}
Abstrak
Tujuan dari penelitian ini adalah untuk mendeskripsikan langkah-langkah penerapan model pembelajaran project based learning (PjBL) dalam meningkatkan kreativitas dan hasil belajar, mengetahui peningkatan kreativitas, dan mengetahui peningkatan hasil belajar. Jenis dari penelitian ini adalah penelitian tindakan kelas (PTK) yang dilakukan dua siklus. Penelitian ini dilaksanakan di SDN Gendongan 02 salatiga dengan subyek penelitian siswa kelas 3 SDN Gendongan 02 dengan jumlah subyek 31.Teknik pengumpulan data menggunakan tehnik tes dan tehnik non tes. Analisis data yang digunakan adalah deskriptif kuantitatif dan kualitatif. Hasil penelitian menunjukan bahwa ada peningkatan kreativitas dan hasil belajar melalui penerapan model pembelajaran Project Based Learning pada siswa kelas 3 SD.Hal tersebut dibuktikan dari meningkatnya rata-rata kreativitas siswa dari kondisi awal atau pra siklus menunjukkan skor rata-rata sebesar 52\% dengan kategori rendah menjadi 68\% skor rata-rata dengan kategori sedang pada siklus I dan pada siklus II skor rata-rata sebesar $81 \%$ dengan kategori tinggi. Peningakatan juga terjadi pada hasil belajar siswa dengan rata-rata nilai siswa hasil belajar pada kondisi awal 65 dengan 15 siswa (48\%)mengalami peningkatan pada siklus 1 dengan rata-rata nilai siswa 72 dengan 21 siswa $(66 \%)$ dan pada siklus 2 rata-rata nilai siswa adalah 79 dengan jumlah siswa tuntas sebanyak 27 atau $(87 \%)$ siswa tuntas.
\end{abstract}

Kata Kunci : Kreativitas Dan Hasil Belajar, Project Based Learning (PjBL)

\begin{abstract}
The purpose of this study is to describe the steps in applying project based learning $(\mathrm{PjBL})$ learning models in enhancing creativity and learning outcomes, knowing increased creativity, and knowing increasing learning outcomes. This type of research is a classroom action research (CAR) conducted two cycles. This research was conducted at SDN Gendongan 02 Salatiga with research subjects grade 3 students at SDN Gendongan 02 with a total of 31 subjects. Data collection techniques used test techniques and non-test techniques. Analysis of the data used is descriptive quantitative and qualitative. The results showed that there was an increase in creativity and learning outcomes through the application of the Project Based Learning learning model for grade 3 students. This was evidenced from the increase in the average creativity of students from the initial or pre-cycle conditions showing an average score of $52 \%$ with a low category to $68 \%$ the average score in the medium category in the first cycle and in the second cycle the average score was $81 \%$ in the high category. Improvement also occurs in student learning outcomes with an average student grade of learning outcomes in the initial conditions 65 with 15 students (48\%) experiencing an increase in cycle 1 with an average grade of 72 students with 21 students (66\%) and in the second cycle average the average student score is 79 with the total number of students as many as 27 or $(87 \%)$ of students completing.
\end{abstract}

Keywords: Creativity and Learning Outcomes, Project Based Learning (PjBL)

@ Jurnal Basicedu Prodi PGSD FIP UPTT 2019

$\triangle$ Corresponding author :

Address :

Email :

ISSN 2580-3735 (Media Cetak)

Phone 
1083 Peningkatan kreativitas dan hasil belajar siswa melalui model pembelajaran Project Based Learning di Sekolah dasar - Richard Adony Natty, Forosalia Kristin, Indri Anugraheni

\section{PENDAHULUAN}

Pada dasarnya setiap orang memiliki potensi kreatif dalam dirinya, tergantung bagaimana cara setiap individu akan mengembangkan dan menumbuhkan potensi kreatif tersebut. Kreativitas adalah hal yang berhubungan dengan penemuan sesuatu, atau mengenai hal yang menghasilkan sesuatu yang baru dengan mengunakan sesuatu yang telah ada. Slameto (2010:145). Dengan kreativitas yang dimiliki, seseorang dapat menciptakan dan menemukan sesuatu yang baru menggunakan ide, gagasan, dan pengetahuan yang dimiliki untuk menghasilkan suatu produk atau karya baru yang berbeda dengan penemuanpenemuan sebelumnya atau sesuatu yang telah ada.

Setiap individu memiliki kemampuan dan kreativitas dengan tingkat yang berbeda Kemampuan dan kreativitas tersebut ada sejak individu lahir dan tidak seorangpun yang tidak memilikinya. Namun yang sering terjadi ialah orang sering tidak menyadari akan hal tersebut dan tidak tahu bagaimana cara mengembangkan potensi kreatif tersebut. Hal ini sering manjadi masalah dalam dunia pendidikan khususnya bagi siswa. Oleh karena itu perlu adanya usaha yang dilakukan oleh pendidik untuk mengatasi masalah tersebut. Dalam proses pembelajaran siswa di harapkan untuk aktif, kreatif, percaya diri dan bertanggung jawab, sehingga pembelajaran tidak hanya terfokus kepada guru tetapi juga melibatkan siswa dalam pembelajaran. Tugas guru hanya menjadi fasilitator dan bukan satu-satunya media bagi siswa, hal ini dilakukan agar siswa dapat melatih dan mengembangkan kemampuan, pengetahuan dan kreativitas yang ada dalam diri siswa. Untuk mengembangkan hal tersebut guru juga perlu mencitpakan suasana kelas dan situasi belajar yang banyak memberikan kesempatan kepada siswa untuk belajar memcahkan masalahmasalah dan beberapa percobaan yang menggunakan konsep atau gagasan siswa sendiri.
Setiap siswa memiliki kemampuan yang berbeda-beda, untuk mengembangkannya siswa diharapkan mempunyai kretaivitas yang tinggi. Dengan adanya kreativitas dapat membantu siswa untuk memnemukan ide, gagasan, dan cara yang baik untuk dapat mengembangkan potensi dalam diri, belajar untuk memecahkan suatu masalah, dan dapat menciptakan atau menemukan sesuatu yang baru berdasrkan teori, konsep dan informasi yang diterima.

Berdasarkan pengamatan dan wawancara di SD Negeri Gendongan 02 Salatiga, guru dalam menyampaikan pembelajaran tematik kepada siswa belum menggunakan metode dan media yang tepat, penerapan metode pembelajaran belum efektif atau konvensional dalam menyampaikan materi pembelajaran kepada siswa. Pembelajaran tematik masih terlalu informatif di bawah dominasi guru (pembelajaran lebih bersifat teacher-centered). Guru dalam menyampaikan materi kepada siswa hanya berjalan satu arah dari guru kepada siswa kemudian banyak siswa yang tidak menyadari pentingnya belajar, khususnya belajar materi yang berkaitan dengan pembelajaran tematik, siswa merasa kesulitan dalam memahami materi yang disampaikan oleh guru, terbukti dari perolehan nilai pada ulangan harian yang masih rendah. Siswa menjadi kurang tertarik untuk memperhatikan penjelasan guru. siswa tidak menunjukkan sikap positif terhadap proses pembelajaran tematik di kelas dan banyak siswa yang tidak menunjukan kreativitas pada saat menyelesaikan tugas yanag diberikan oleh guru. Sehingga pembelajaran tematik dianggap sebagai pelajaran yang sulit dan menjemukan.

Kecenderungan pembelajaran tematik di SD Negeri Gendongan 02 Salatiga adalah siswa hanya mempelajari pembelajaran tematik sebagai produk, menghafalkan konsep, dan teori. Akibatnya pembelajaran tematik sebagai proses, 


\section{Peningkatan kreativitas dan hasil belajar siswa melalui model pembelajaran Project Based}

Learning di Sekolah dasar - Richard Adony Natty, Forosalia Kristin, Indri Anugraheni

sikap, dan aplikasi tidak tersentuh dalam pembelajaran. siswa kelas 3 di SD Negeri Gendongan 02 Salatiga tidak dibiasakan untuk mengembangkan potensi berpikirnya. Sehingga siswa cenderung menjadi malas berpikir secara mandiri sehingga kreativitas belajar siswa rendah. Dari 31 siswa belum mencapai tingkat kreativitas belajar yang diharapakan hasil observasi kreativitas belajar siswa diperoleh data bahwa dari 14 siswa, 58\% kreativitasnya rendah, 11 siswa $46 \%$ kreativitasnya sedang dan 0 siswa $0 \%$ kreativitasnya tinggi. Dengan demikian dapat disimpulkan bahwa hasil belajar, kreativitas siswa dalam pembelajaran tersebut kurang. Hal tersebut terjadi, dikarenakan guru belum membuat siswa ikut terlibat aktif dalam proses pembelajaran. Hal lain ditunjukkan dengan hasil belajar siswa yang rendah. Hasil belajar siswa yang rendah dapat dilihat dari nilai ulangan harian siswa pada mata pembelajaran tematik yang menunjukkan dari 31 siswa 15 siswa atau $48 \%$ berada di atas KKM dan 16 siswa atau $52 \%$ masih berada di bawah KKM. Standar ketuntasan minimum untuk pelajaran tematik kelas 3 SD Negeri Gendongan 02 Salatiga adalah KKM 70.

Berdasarkan data yang diperoleh, rendahnya kreativitas dan hasil belajar siswa karena masih terdapat siswa yang belum berani mengungkapkan gagasan, ide-ide baru mereka, dan kurangnya wadah untuk mengekspresikan dan berpendapat sesuai dengan kreativitas masingmasing siswa. Sehingga dalam proses pembelajaran perlu menciptakan inovasi pembelajaran yang menyenangkan dan mendorong siswa untuk mampu mengekspresikan kreativitas dan dapat meningkatkan hasil belajar siswa yaitu dengan menggunakan model pembelajaran project based learning ( $\mathrm{PjBL})$

Model pembelajaran Project Based Learning (PjBL) menurut Warsono \& Hariyanto (2012:153) adalah suatu pengajaran yang mencoba mengaitkan antara teknologi dengan masalah kehidupan sehari-hari yang akrab dengan siswa, atau dengan suatu proyek sekolah. Dalam model pembelajaran Project Based Learning $(\mathrm{PjBL})$, siswa akan dihadapakan pada suatu masalah atau diberikan suatu proyek yang berkaitan dengan materi dan kemudian siswa akan diminta untuk memecahkan atau membuat suatu projek/kegiatan berdasarkan pertanyaan serta permasalahan yang kemudian dilanjutkan dengan proses mencari, menyelidiki, dan menemukan sendiri sehingga siswa memperoleh pengetahuannya secara lengkap dengan menggunakan ide, atau gagasan-gagasan baru yang di peroleh baik dari teori, konsep, informasi yang telah dikembangkan menjadi sesuatu yang baru dan berbeda. Dalam model Pembelajaran ini juga dapat melatih siswa untuk bekerja secara mandiri maupun dalam kelompok untuk membuat dan menghasilkan sesuatu.

Model pembelajaran Project Based Learning (PjBL), siswa akan dihadapakan pada suatu masalah atau diberikan suatu proyek yang berkaitan dengan materi dan kemudian siswa akan diminta untuk memecahkan atau membuat suatu projek/kegiatan berdasarkan pertanyaan serta permasalahan yang kemudian dilanjutkan dengan proses mencari, menyelidiki, dan menemukan sendiri sehingga siswa memperoleh pengetahuannya secara lengkap dengan menggunakan ide, atau gagasan-gagasan baru yang di peroleh baik dari teori, konsep, informasi yang telah dikembangkan menjadi sesuatu yang baru dan berbeda. Dalam model Pembelajaran ini juga dapat melatih siswa untuk bekerja secara mandiri maupun dalam kelompok untuk membuat dan menghasilkan sesuatu.

Kristin (2016:11) kreativitas merupakan kemampuan yang dimiliki seseorang untuk menghasilkan suatu hal yang baru baik dari ide, 
1085 Peningkatan kreativitas dan hasil belajar siswa melalui model pembelajaran Project Based Learning di Sekolah dasar - Richard Adony Natty, Forosalia Kristin, Indri Anugraheni

dan gagasan yang dimilikinya akan menghasilkan sesuatu yang memiliki daya guna. Slameto menambahkan bahwa berpikir, memecahkan masalah dan menghasilkan sesuatu yang baru adalah suatu kegiatan yang kompleks dan berhubungan erat satu dengan yang lain. Suatu masalah umumnya tidak dapat dipecahkan tanpa berpikir, dan banyak masalah memerlukan pemecahan yang baru bagi orang-orang atau kelompok. Sebaliknya, menghasilkan sesuatu ( benda-benda, gagasan ) yang baru bagi seseorang, menciptakan sesuatu, itu mencakup pemecahan masalah. Penguasaan informasi itu perlu untuk memperoleh konsep dan prinsip keduanya itu harus diingat dan dipertimbangkan dalam pemecahan masalah dan perbuatan kreatif (Slameto, 2010:139).

Beberapa uraian diatas dari kedua pendapat diatas dapat di kemukakan bahwa kreativitas pada intinya merupakan kemampuan seseorang untuk melahirkan sesuatu yang baru, baik berupa gagasan maupun karya nyata, baik dalam bentuk karya baru maupun kombinasi dari hal-hal yang sudah ada, yang semuanya itu relatif berbeda dengan apa yang sudah ada sebelumnya. Untuk itu dalam melangsungkan pembelajaran siswa dituntut untuk kreatif karena didalam kegiatan belajar mengajar, guru sering melihat siswa kurang fokus dalam belajar dan siswa yang sering mengobrol pada saat pembelajaran berlangsung dan siswa hanya bertindak sebagai pendengar saja. Peran siswa tidak lebih sebagai pendengar setia. Dengan kata lain, pembelajaran terjadi lebih mengarah kepada teacher center. Hal tersebut akan mempengaruhi tingkat kreativitas belajar siswa. Untuk itu penulis menggunakan model pembelajaran Project Based Learning (PjBL) dan diharapkan model ini dapat menstimulus siswa untuk berani menunjukkan kreativitasnya dalam kegiatan pembelajaran yang berlangsung.
Proses kreatif melibatkan pemilihan unsurunsur penting yang diketahui dari berbagai macam bidang dan menyatukannya menjadi format-format yang baru, menggunakan informasi dalam situasisituasi yang baru, menggambarkan aspek-aspek pengalaman, pola-pola dan analogi serta prinsipprinsip mendasar yang tak berhubungan. Aspek ini memungkinkan orang yang sedang menyelesaikan suatu masalah untuk memunculkan solusi-solusi yang berbeda dan yang tadinya tidak terlihat dengan jelas. Penyelesaian suatu masalah yang kreatif dapat dikembangkan secara ekstensif dalam bidang sains, bidang matematika, dan bidang bisnis, misalnya sebuah kualitas yang banyak dibutuhkan dalam iklim ekonomi saat ini (Florence Beetlestone,2012:4-5). Dalam proses belajar setiap orang atau siswa dituntut untuk dapat mengembangkan, mencipta, dan menemukan ide atau gagasan baru dari apa yang telah dipelajari melalui proses berpikir dan kreativitas yang tinggi sehingga dapat menemukan sesuatu yang baru dan berbeda dengan penemuan sebelumnya baik berupa gagasan atau karya nyata berdasarkan data dan informasi-informasi yang ada, atau bahkan dengan adanya kreativitas seseorang mampu menyelesaikan suatu masalah dengan metode atau cara-cara tertentu. Setiap orang pada dasarnya sudah memiliki kreativitas dalam dirinya masingmasing, kreativitas tersebut akanberkembang jika adanya usaha-usaha yang dilakukan untuk menumbuhkan potensi kreatif tersebut. Oleh karena itu untuk mencapai kreativitas diperlukan rasa percaya diri, rasa ingin tahu, minat, dan motivasi yang tinggi dalam diri sesorang untuk dapat menghasilkan ide-ide baru.

Berdasarkan beberapa pendapat yang dikemukakan diatas, maka dapat disimpulkan kreativitas yang dimiliki siswa dapat mewujudkan dirinya sehingga lancar dan luwes dalam berpikir dan dapat melihat masalah dari berbagai sudut pandang serta mampu melahirkan banyak gagasan, 
1086 Peningkatan kreativitas dan hasil belajar siswa melalui model pembelajaran Project Based Learning di Sekolah dasar - Richard Adony Natty, Forosalia Kristin, Indri Anugraheni

karena kreativitas merupakan suatu proses yang dilakukan oleh seseorang untuk menemukan, mencipta, menggabungkan dan mengkreasikan suatu gagasan atau ide yang ada menjadi sesuatu yang baru berdasarkan informasi dan data-data yang ada.

Indikator-indikator siswa yang kreatif dalam belajar menurut Hamzah (2010:54); a) Memiliki rasa ingin tahu yang besar, Sering mengajukan pertanyaan yang berbobot, Memberikan banyak gagasan dan usul terhadap suatu masalah, Mengatakan pendapat secara spontan dan tidak malu-malu. Dapat bekerja sendiri;b) Senang mencoba hal-hal baru. Dalam penelitian tindakan kelas ini indikator-indikator yang ada akan digunakan untuk mengukur kreativitas siswa adalah indikator yang dikaitkan dengan proses belajar kelompok siswa, maka indikator yang akan diamati adalah;1) memiliki rasa ingin tahu yang besar;2)sering mengajukan pertanyaan yang berbobot;3)mengatakan pendapat secara spontan dan tidak malu-malu;4) dapat bekerja sendiri.

Pembelajaran berbasis proyek/tugas terstruktur (Project-Based Learning) merupakan pendekatan pembelajaran yang membutuhkan suatu pembelajaran yang komprehensif dimana lingkungan belajar siswa (kelas) didesain agar siswa dapat melakukan penyelidikan terhadap masalah autentik termasuk pendalaman materi suatu materi pembelajaran, dan melaksanakan tugas bermakna lainnya Depdiknas (2003:7). Model pembelajaran Project Based Learning (PjBL) adalah suatu model kegiatan dikelas yang berbeda dengan biasanya. Kegiatan pembelajaran berbasis proyek berjangka waktu lama, antar disiplin, berpusat pada siswa dan terintegrasi dengan masalah dunia nyata. Model pembelajaran Project Based Learning (PjBL) menurut Warsono \& Hariyanto (2012:153) adalah suatu pengajaran yang mencoba mengaitkan antara teknologi dengan masalah kehidupan sehari-hari yang akrab dengan siswa, atau dengan suatu proyek sekolah.

Berdasarkan pendapat para ahli tersebut dapat disimpulkan bahwa model pembelajaran Project Based Learning (PjBL) merupakan model pembelajaran yang lebih mengedepankan pengalaman siswa dengan memberikan waktu dan kesempatan kepada siswa baik secara individu maupun kelompok untuk dapat memecahkan/menyelesaikan masalah yang diberikan terkait dengan materi dan sesuai dengan keadaan lingkungan untuk dapat meningkatkan kreativitas siswa, membantu siswa menemukan ide-ide baru, membuat dan menciptakan suatu karya/produk berdasarkan konsep-konsep, teori atau informasi yang diperoleh.

Pembelajaran berbasis proyek menurut Hosnan (2014:325) meliputi langkah-langkah sebagai berikut; a) penentuan; b) proyek; Penentuan proyek dapat berupa tugas langsung atau dari permasalahan-permaslahan yang harus diselesaikan; c) perancangan langkah-langkah penyelesaian proyek; d) menyusun langkahlangkah kegiatan yang akan dalam penyelesaian tugas atau proyek; e) penyusunan jadwal pelaksanaan proyek; f) meliputi penyusunan jadwal sesuai langkah-langkah untuk menyelesaikan tugas atau proyek yang telah ditentukan sebelumnya; g) penyelesaian proyek dengan fasilitasi dan monitoring guru. Hal ini meliputi penyelesaian proyek dengan melakukan aktifitas penyelesaian proyek seperti yang telah diranvang sebelumnya dengan bimbingan dan pengawasan guru.; a) penyusunan laporandan presentasi atau publikasi; b) penyusunan laporan dan publikasi berdasarkan penyelesaian tugas yang dikomunikaskan kepada teman-teman lain dan guru;c) evaluasi proses dan hasil proyek;d) Kegiatan ini mencakup refleksi atas aktivitas dan hasil tugas atau proyek yang telah dikerjakan. 
1087 Peningkatan kreativitas dan hasil belajar siswa melalui model pembelajaran Project Based Learning di Sekolah dasar - Richard Adony Natty, Forosalia Kristin, Indri Anugraheni

Sedangkan menurut Rais (2010:8-9) langkahlangkah model pembelajaran Project Based Learning (PjBL) adalah sebagai berikut;1) Pembelajaran dimulai dengan pertanyaan yang dapat memberi penugasan pada siswa untuk melakukan suatu aktivitas. Topik hendaknya sesuai dengan realita dunia nyata dan dimulai dengan investigasi mendalam ;2) Merencanakan proyek, Perencanaan dilakukan secara bersamasama antara guru dengan siswa sehingga siswa diharapakan akan merasa memiliki atas proyek tersebut. Perencanaan berisi tentang aturan main, pemilihan kegiatan yang dapat mendukung dalam menjawab pertanyaan-pertanyaan esensial dengan mengintegrasikan berbagai subjek yang mendukung, serta menginformasikan alat dan bahan yang akan digunakan untuk menyelesaikan proyek;3) Menyusun jadwal aktivitas, Guru bersama dengan siswa menyusun jadwal kegiatan dalam menyelesaikan proyek. Waktu penyelesaian proyek harus jelas, dan siswa diberi arahan untuk mengelola waktu yang ada. Siswa mencoba menggali sesuatu yang baru, akan tetapi guru juga harus tetap mengingatkan apabila kegiatan siswa melenceng dari tujuan proyek. Proyek yang dilakukan oleh siswa adalah proyek yang membutuhkan waktu yang lama dalam pengerjaannya, sehingga siswa dapat menyelesaikan proyeknya secara berkelompok di luar jam sekolah. Pada saat jam pembelajaran dilakukan sekolah, siswa akan mempresentasikan hasil proyeknya di kelas;4) Mengawasi jalannya proyek,Guru akan melakukan monitor terhadap aktivitas siswa selama menyelesaikan proyek. Monitoring dilakukan dengan cara memfasilitasi siswa pada setiap proses. Dengan kata lain, guru berperan sebagai mentor bagi aktivitas siswa. Guru mengajarkan kepada siswa bagaimana bekerja dalam sebuah kelompok. Siswa dapat memilih perannya masing-masing dengan tidak mengesampingkan kepentingan kelompok;5)
Penilaian terhadap produk yang dihasilkan, Penilaian ini dilakukan untuk membantu guru mengukur ketercapaian standar, berperan dalam mengevaluasi kemajuan masing-masing siswa, memberi umpan balik tentang tingkat pemahaman yang sudah dicapai oleh siswa, dan membantu guru dalam menyusun strategi pembelajaran berikutnya. Penilaian produk dilakukan saat masing-masing kelompok mempresentasikan produknya di depan kelompok lain secara bergantian;6) Evaluasi,Pada akhir proses pembelajaran, guru dan siswa melakukan refleksi terhadap aktivitas dan hasil proyek yang sudah dijalankan. Proses refleksi dilakukan baik secara individu maupun kelompok. Pada tahap ini, siswa diminta untuk mengungkapkan perasaan dan pengalamannya selama menyelesaikan proyek

Dari kedua pendapat diatas dapat disimpulkan bahwa model pembelajaran project based learning (PjBL). merupakan model pembelajaran yang melibatkan seluruh siswa dalam proses pembelajaran dan memberikan lebih banyak waktu kepada siswa untuk menyelesaikan suatu masalah secara individu maupun kelompok sesuai dengan teori, konsep, atau informasi yang diperoleh siswa. Sintak model pembelajaran Project Based Learning (PjBL).

\section{METODE}

Jenis penelitian yang akan dilakukan adalah Penelitian Tindakan Kelas (PTK) Penelitian ini berdasarkan pada siklus, satu siklus dilaksanankan dua kali pertemuan melalui proses pengkajian berdaur yang terdiri dari 3 tahap, yaitu: 1) tahap perencanaan tindakan (Planning) 2) tahap pelaksanaan tindakan (Action) dan obervasi (observation), serta 3) tahap refleksi. Penelitian tindakan kelas ini bertujuan untuk meningkatkan kreativitas dan hasil belajar matematika siswa kelas 3 melalui penggunaan model pembelajaran Project Based Learning (PjBL). Penelitian 
1088 Peningkatan kreativitas dan hasil belajar siswa melalui model pembelajaran Project Based Learning di Sekolah dasar - Richard Adony Natty, Forosalia Kristin, Indri Anugraheni

dilaksanakan di kelas 3 SD Negeri Gendongan 02

Salatiga Tahun Pelajaran 2019/2020. Subjek penelitian yaitu siswa kelas 3 berjumlah 31 siswayang terdiri dari 16 orang laki-laki dan 15 sisanya perempuan,Teknik pengambilan data yaitu observasi rubrik kreativitas dan test pilihan ganda. teknik analisis data berupa teknik analisis deskriptif kuantitatif

\section{HASIL DAN PEMBAHASAN}

Hasil belajar tematik tema 2 sub 3 dan 4 diperoleh dari hasil tes evaluasi siswa tiap siklus. Hasil belajar siswa disajikan dalam bentuk tabel distribusi frekwensi. Pada penelitian ini data akan dianalisis dengan dua tahapan yaitu analisis ketuntasan dan analisis komparatif. Data yang dianalisis adalah data hasil belajar tematik tema 2 sub 3 dan 4 materi siswa kelas 3 SDN Gendongan 02 Salatiga semseter 1 tahun ajaran 2019/2020.
Analisis ketuntasan tiap siklus dalam tabel ketuntasan diolah dengan membandingkan data mentah dengan skor KKM untuk mata pelajaran tematik tema 2 sub 3 dan 4. Ketuntasan kreativitas dan hasil belajar siswa.

Kreativitas siswa dengan menerapakan model pembelajaran Project Based Learning (PjBL) selama proses pembelajaran tematik tema 2 sub tema 3 pada setiap siklusnya menunjukkan adanya peningkatan. Langkah awal untuk mengetahui kreativitas siswa dilakukan pada pra siklus guna mengetahui tindakan yang akan diberikan. Kemudian dilakukan siklus I dan siklus II untuk mengetahui pencapaian siswa selama model pembelajaran Project Based Learning (PjBL). Berikut ini disajikan tabel 7 peningkatan kreativitas siswa dari pra siklus, siklus I sampai siklus II.

\section{Tabel 1 Perbandingan Hasil Data Kretivitas Siswa}

\begin{tabular}{|c|c|c|c|c|c|c|c|}
\hline \multirow[t]{2}{*}{ Rentang Skor } & \multirow{2}{*}{$\begin{array}{c}\text { Kategori } \\
\text { Kretifitas }\end{array}$} & \multicolumn{2}{|c|}{ Pra Siklus } & \multicolumn{2}{|c|}{ Siklus I } & \multicolumn{2}{|c|}{ Siklus II } \\
\hline & & Jumlah & $\%$ & Jumlah & $\%$ & Jumlah & $\%$ \\
\hline$\geq 80$ ke atas & Tinggi & 0 & $3 \%$ & 6 & $19 \%$ & 26 & $84 \%$ \\
\hline $60-79$ & Sedang & 15 & $48 \%$ & 21 & $68 \%$ & 5 & $16 \%$ \\
\hline$\leq 59$ & Rendah & 16 & $52 \%$ & 4 & $13 \%$ & 0 & $0 \%$ \\
\hline \multicolumn{2}{|c|}{ Jumlah } & 31 & $100 \%$ & 31 & $100 \%$ & 31 & $100 \%$ \\
\hline
\end{tabular}

Keterangan:

$\mathrm{F}=$ Frekuensi/Banyaknya Siswa

$\%=$ Kreativitas Siswa

Tabel 1 diatas, dapat diketahui bahwa dari pra siklus sampai pelaksanan siklus II terjadi peningkatan terhadap kreativitas siswa. Pada pra siklus, siswa yang berada dalam kategori tinggi sebanyak 0 siswa atau $0 \%$ dari jumlah siswa. Kemudian setelah dilakukan siklus I, siswa yang berada pada kategori tinggi meningkat menjadi 6 siswa atau $19 \%$ selanjutnya meningkat menjadi 26 siswa atau $84 \%$. Persentase ini meningkat kembali pada siklus II sehingga didapati siswa yang berada dalam kategori tinggi sebanyak siswa dengan persentase sebesar $84 \%$. Selanjutnya siswa yang berada dalam kategori sedang pada pra siklus menunjukkan persentase sebesar $48 \%$ atau 15 siswa dalam kategori sedang. Setelah dilakukan siklus I, persentase ini meningkat sebesar $68 \%$ atau 21 siswa dalam kategori. Kemudian, siswa yang berada dalam kategori rendah yang ditunjukkan pada pra siklus menunjukkan persentase yang cukup banyak yaitu 52\% dengan jumlah 16 siswa. Setelah dilakukan siklus I, persentase ini meningkat sebesar $13 \%$ atau 4 siswa dalam kategori sedang. Setelah dilakukan siklus II jumlah siswa dalam kategori rendah menurun menjadi 0 siswa dengan persentase sebesar 0\%. Hasil ini terus menunjukkan 
perubahan yang baik, dimana pada siklus II sudah tidak ada lagi siswa yang berada dalam kategori rendah pada kreativitas siswa

Berdasarkan peningkatan persentase kreativitas diketahui bahwa pada pra siklus skor maksimal dari kreativitas siswa yang diperoleh siswa adalah 11 dan skor minimalnya adalah 5 , sedangkan skor rata-rata yang diperoleh siswa dalam satu kelas adalah 9. Setelah dilakukan siklus I, skor maksimal yang diperoleh siswa meningkat menjadi 15 dengan skor minimalnya yang diperoleh siswa adalah 8. Hal ini meningkatkan pula skor ratarata kreativitas siswa menjadi 11 . Peningkatan ini semakin menunjukan adanya perubahan siswa yang baik, dimana pada siklus II, skor maksimal yang diperoleh siswa mencapai 16. Selain itu, skor minimal yang diperoleh siswa juga semakin meningkat mencapai 10, sehingga skor rata-rata kelas yang diperoleh siswa menjadi 13. Hasil ini sudah memenuhi indikator kinerja yang telah ditetapkan peneliti, yaitu meningkatkan kreativitas siswa supaya berada dalam kategori tinggi sebesar 84\%. Dari tabel 4.7 diatas dapat diketahui bahwa persentase siswa yang berada dalam kategori tinggi adalah $84 \%$, sehingga penerapan model pembelajaran Project Based Learning (PjBL) ini berhasil meningkatkan kretivitas siswa kelas 3 .

Berdasarkan hasil penelitian yang telah dilakukan menggunakan model pembelajaran Project Based Learning (PjBL) pada mata pelajaran tematik tema 2 sub tema 3 dan 4 terjadi peningkatan hasil belajar siswa. Peningkatan tersebut dapat dilihat pada perbandingan nilai pra siklus, siklus I dan siklus II tabel 8 berikut:

\section{Tabel 2 Perbandingan Hasil Belajar Tematik Pra Siklus, Siklus I dan Siklus II}

\begin{tabular}{ccccccc}
\hline \multirow{2}{*}{ Kriteria } & \multicolumn{2}{c}{ Pra Siklus } & \multicolumn{2}{c}{ Siklus I } & \multicolumn{2}{c}{ Siklus II } \\
\cline { 2 - 7 } & Jumlah & Persentase & Jumlah & Persentase & Jumlah & Persentase \\
\hline Tuntas & 15 & $48 \%$ & 21 & $66 \%$ & 27 & $87 \%$ \\
\hline Tidaktuntas & 16 & $52 \%$ & 10 & $32 \%$ & 6 & $13 \%$ \\
\hline Jumlah & 31 & $100 \%$ & 31 & $100 \%$ & 31 & $100 \%$ \\
\hline Nilai Tertinggi & & 80 & & 85 & & 95 \\
\hline Nilai Terendah & & 40 & & 50 & & 60 \\
\hline Nilai Rata-Rata & & 65 & & 72 & & \\
\end{tabular}

sedangkan 15 siswa atau (48\%) memiliki kretivitas

Tabel 2 dapat dilihat adanya peningkatan jumlah ketuntasan hasil belajar siswa. yang semula pada pra siklus sebelum diadakannya tindakan, ketuntasan siswa hanya mencapai $48 \%$, setelah model pembelajaran Project Based Learning (PjBL) meningkatkan menjadi 66\% kemudian setelah tindakan dilakukan dalam 2 siklus hasil belajar siswa meningkat lagi mencapai $87 \%$ dari jumlah keseluruhan siswa

Hasil penelitian yang telah dilaksanakan pada kelas 3 SD Negeri Gendongan 02 Salatiga diketahui bahwa, Sebelum dilakukan tindakan atau pada pra siklus terdapat 0 siswa atau $(0 \%)$ yang memiliki kretivitas siswa pada kategori tinggi, siswa pada kategori sedang, 16 siswa atau (52\%) memiliki kretivitas siswa pada kategori rendah kemudian dilaksanakan siklus I terdapat 6 siswa atau (19\%) yang memiliki kretivitas siswa pada kategori tinggi, sedangkan 21 siswa atau (68\%) memiliki kretivitas siswa pada kategori sedang, 4 siswa atau( $13 \%)$ memiliki kretivitas siswa pada kategori rendah. Berarti terjadi peningkatan sebanyak (19\%). Akan tetapi hasil yang diperoleh pada siklus I belum memenuhi target sesuai dengan indikator kerja yang telah dibuat yaitu ketuntasan mencapai $(80 \%)$ atau lebih dari keseluruhan siswa. Memperhatikan refleksi dari siklus I, maka dilakukan perencanaan perbaikan-perbaikan pembelajaran yang akan dilakukan pada siklus II 
1090 Peningkatan kreativitas dan hasil belajar siswa melalui model pembelajaran Project Based Learning di Sekolah dasar - Richard Adony Natty, Forosalia Kristin, Indri Anugraheni

agar penelitian mencapai target yang ditentukan. Setelah dilakukan tindakan siklus II dari 31 terdapat 27 siswa atau (87\%) yang memiliki kretivitas siswa pada kategori tinggi, sedangkan 4 siswa atau (13\%) memiliki kretivitas siswa pada kategori sedang, 0 siswa memiliki kretivitas siswa pada kategori rendah. Pada kondisi siklus II terdapat 31 siswa yang memiliki kretivitas siswa pada kategori tinggi. Hasil yang diperoleh pada siklus II ini telah mencapai target yaitu ketuntasan siswa mencapai (80\%). Hasil penelitian ini sesuai dengan penelitian yang sudah dilakukan sebelumnya oleh Maria Kristiani (2019) dengan mengggunakan model pembelajaran Project Based Learning (PjBL) meningkatkan hasil belajar pembelajaran tematik kelas IV. Meningkatnya kreativitas belajar pada tiap siklusnya sesuai dengan pendapat dari Komarudin (2011:279) mengatakan bahwa kreativitas biasanya diartikan sebagai kemampuan untuk menciptakan suatu produk baru.

Pada kondisi hasil belajar sebelum dilakukan tindakan atau pada pra siklus siswa yang tuntas hanya sebanyak 15 siswa atau(48\%) kemudian dilaksanakan siklus I ketuntasan siswa meningkat mencapai 21 siswa atau $(68 \%)$. Berarti terjadi peningkatan sebanyak (20\%). Akan tetapi hasil yang diperoleh pada siklus I belum memenuhi target sesuai dengan indikator kerja yang telah dibuat yaitu ketuntasan mencapai $(80 \%)$ atau lebih dari keseluruhan siswa. Dengan memperhatikan refleksi dari siklus I, maka dilakukan perencanaan perbaikan-perbaikan pembelajaran yang akan dilakukan pada siklus II agar penelitian mencapai target yang ditentukan. Setelah dilakukan tindakan siklus II, ketuntasan siswa mencapai (87\%) dari 31 siswa 27 yang tuntas, ini berarti Penelitian Tindakan Kelas dengan menggunakan model pembelajaran Project Based Learning (PjBL) meningkatkan ketuntasan siswa sebanyak (20\%) dibandingkan hasil belajar sebelum dilakukan tindakan. Hasil yang diperoleh pada siklus II ini telah mencapai target yaitu ketuntasan siswa mencapai (87\%). Hal ini dikarenakan kelebihan dengan menggunakan model pembelajaran Project Based Learning (PjBL). Hasil penelitian ini sesuai dengan penelitian yang sudah dilakukan sebelumnya oleh Cahyadi (2019) dengan mengggunakan model pembelajaran Project Based Learning (PjBL) dapat meningkatan hasil belajar tematik terpadu pada siswa sekolah dasar.

Penelitian ini relevan dengan hasil penelitian Umi Faizah (2015) tentang Penerapan Pendekatan Saintifik Melalui Model Project Based Learning untuk Meningkatkan Ketrampilan Proses Dan Hasil Belajar Siswa Kelas IV SD Negeri Seworan, Wonosegoro. Ni Made Nepri Andari. 2016. Tentang Penerapan Model Project Based Learning Bororientasi Pendidikan Karakter Untuk Meningkatkan Hasil Belajar IPA Siswa Kelas IV SDN Dangin Putri.

Hal ini sejalan dengan pendapat Warsono \& Hariyanto (2012:153) bahwa model pembelajaran Project Based Learning (PjBL) merupakan suatu pengajaran yang mencoba mengaitkan antara teknologi dengan masalah kehidupan sehari-hari yang akrab dengan siswa, atau dengan suatu proyek sekolah. Dalam pembelajaran ini siswa mampu mengelola dan memecahkan masalah yang ada dan mampu mengembangkan kreativitas berfikir dalam bentuk produk.

Yang membedakan penelitian ini dengan penelitian sebelumnya yaitu penelitian ini menggunakan model pembelajaran Project Based Learning untuk mengukur kreativitas dan hasil belajar siswa. Penelitian ini menggunakan alat ukur kreativitas dengan rubik skor tinggi, sedang, dan rendah dan dalam proses pembelajaran siswa diminta untuk membuat tugas proyek atau produk sendiri, dimana siswa mencari ide sendiri 
mengenai produk tersebut yang berhubungan dengan materi yang dipelajari. Siswa akan merencanakan tugas proyek apa yang akan dibuat dengan bimbingan guru, kemudian siswa secara berkelompok ataupun individu menjadwalkan untuk penyelesaian tugas proyek tersebut. Jika sudah terbuat setiap kelompok atau individu akan membuat laporan akhir mengenai tugas proyek yang kemudian akan presentasikan secara di depan kelas. Setelah itu siswa mengerjakan soal evaluasi sebagai bentuk penilaian hasil belajar yang sesuai dengan indikator pembelajaran.

Dari hasil pemaparan, dapat diperoleh kesimpulan bahwa model pembelajaran Project Based Learning (PjBL) yang peneliti lakukan dapat dikatakan berhasil. Model pembelajaran Project Based Learning (PjBL) akan dapat menambah motivasi, rasa percaya diri, toleransi, kerjasama dan juga pemahaman materi siswa. Hal ini yang menjadikan kreativitas dan hasil belajar tematik tema 2 sub tema 3 dan 4 siswa di Kelas 3 SD Negeri Gendongan 02 Salatiga, pada materi pecahan menjadi meningkat

\section{SIMPULAN}

Berdasarkan hasil temuan dan pembahasan yang telah dipaparkan dapat disimpulkan bahwa penggunaan model pembelajaran Project Based Learning $(P j B L)$ telah berhasil meningkatkan kreativitas siswa dan hasil belajar siswa tematik tema 2 sub tema 3 dan 4 pada siswa kelas 3 SD Negeri Gendongan 02 Salatiga semester I Tahun 2019/2020. Hal ini ditunjukkan dengan perbandingan kreativitas siswa pra siklus, siswa yang berada dalam kategori tinggi sebanyak 0 siswa atau 0\% dari jumlah siswa. Kemudian setelah dilakukan siklus I, siswa yang berada pada kategori tinggi meningkat menjadi 6 siswa atau $19 \%$ selanjutnya meningkat menjadi 26 siswa atau $84 \%$. pada siklus II. Selanjutnya siswa yang berada dalam kategori sedang pada pra siklus menunjukkan persentase sebesar $48 \%$ atau 15 siswa dalam kategori sedang. Setelah dilakukan siklus I, persentase ini meningkat sebesar $68 \%$ atau 21 siswa dalam kategori sedang. Kemudian siswa yang berada dalam kategori rendah yang ditunjukkan pada pra siklus menunjukkan persentase yang cukup banyak yaitu 52\% dengan jumlah 16 siswa.

Setelah dilakukan siklus I, persentase ini menurun sebesar 52\% atau 16 siswa dalam kategori sedang. Setelah dilakukan siklus II jumlah siswa dalam kategori rendah menurun menjadi 0 siswa dengan persentase sebesar $0 \%$. Hasil ini terus menunjukkan perubahan yang baik, dimana pada siklus II sudah tidak ada lagi siswa yang berada dalam kategori rendah pada kreativitas siswa. dan hasil belajar tematik tema 2 sub tema 3 berdasarkan ketuntasan belajar dengan $K K M \geq 70$. Hasil analisis diketahui bahwa dari 31 siswa yang tuntas sebelum tindakan adalah 15 siswa (48\%). Setelah diberikan tindakan pada siklus I terjadi peningkatan jumlah ketuntasan siswa menjadi 21 siswa (66\%). Setelah diberikan tindakan pada siklus II, terjadi lagi peningkatan jumlah ketuntasan menjadi 27 siswa $(87 \%)$. siswa yang belum tuntas sebelum diberikan tindakan adalah 16 siswa (52\%). Setelah diberikan tindakan pada siklus I, berkurang menjadi 10siswa (32\%). Setelah dilaksanakan lagi tindakan pada siklus II, menjadi 6 siswa (13\%) yang belum tuntas.

Penggunakan model pembelajaran project based learning (PjBL). dalam kegiatan pembelajaran dapat meningkatkan hasil belajar tematik tema 2 sub tema 3 kelas 3 SD Negeri Gendongan 02 Salatiga semester I Tahun 2019/2020 semester I tahun pelajaran 2019/2020 yaitu dengan menerapkan pembelajaran sesuai dengan langkah-langkah pembelajaran secara urut. Pembelajaran menggunakan model pembelajaran 
1092 Peningkatan kreativitas dan hasil belajar siswa melalui model pembelajaran Project Based

Learning di Sekolah dasar - Richard Adony Natty, Forosalia Kristin, Indri Anugraheni

Project Based Learning (PjBL). salah sutu model pembelajaran kooperatif yang berisi turnamen akademik dengan melibatkan aktivitas seluruh siswa yang memiliki kemampuan, jenis kelamin dan suku atau ras yang berbeda. Dan juga suatu model pembelajaran kooperatif dimana bagiannya terdiri dari penyampaian materi secara klasikal, pengelompokan, pembelajaran ini merupakan salah-satu model pembelajara kreatif dan efektif yang berfokus pada pemecahan masalah, ineteraksi antar siswa, kreativitas berfikir, dan menciptakan atau membuat suatu karya/proyek baik secara individu maupun kelompok. Model pembelajaran Project Based Learning (PjBL) akan dapat menambah motivasi, rasa percaya diri, toleransi, kerjasama dan juga pemahaman materi siswa

\section{DAFTAR PUSTAKA}

Andita Putri Surya. 2018. Penerapan Model Pembelajaran Project Based Learning (PjBL) untuk Meningkatkan Hasil Belajar dan Kreativitas Siswa Kelas 3 SDN Sidorejo Lor 01 Salatiga.Jurnal Pesona Dasar, Vol. 6. (1)41-54

Beetlestone, Florence. 2012. "Creative Learning. Strategi Pembelajaran Untuk Melesatkan Kreativitas Siswa”. Bandung. Nusa Media.

Depdiknas. 2003. Manajemen Mutu Berbasis Sekolah. Jakarta: Direktorat Pendidikan Dasar dan Menengah.

Edi Cahyadi,2019.Peningkatan Hasil Belajar Tematik Terpadu Melalui Model Project Based learning Pada Siswa Sekolah Dasar. Jurnal Riset Teknologi dan Inovasi Pendid ikan Volume 2,(1)205-218

Hamzah B. Uno, dkk. 2010. Menjadi Peneliti PTK yang Profesional. Jakarta: Bumi Aksara.

Hosnan, Muhammad. 2014. Pembelajaran Saintifik dan Kontektual Dalam Pembelajara Abat 21.Bogor Ghalia Indonesia.

Juwita Tindaon dan Deny Setiawan. 2015. Penerapan Pembelajaran Project Based Learning Menggunakan Media Audio Visual dalam Meningkatkan Hasil Belajar PPKn dan Pembentukan Karakter Siswa kelas IV SD Negeri 094102 Sambosar
Kecamatan Raya Kahean Kabupaten Simalungun Tahun Ajaran 2014/2015. Jurnal Tabularasa PPSUnimed Vol.12.(1) 23-30

Komarudin, D.2018. Hubungan antara kreativitas dengan prestasi belajar siswa. Psympathic: Jurnal Ilmiah Psikologi, 4(1)278-288

Kristin,F.2016 . “Analisis Model Pembelajaran Discovery Learning Dalam Meningkatkan Hasil Belajar Siswa" Sd. Jurnal Pendidikan Dasar Perkhasa, 2(1).

Maria Kristiani,2017. Penerapan Model Project Based Learning Berbantuan Pop-Up Book Untuk Meningkatkan Hasil Belajar Pembelajaran Tematik Kelas IV Kalam Cendekia, Volume 6, (2.1)1- 6

Muh. Rais. 2010. Project based learning: Inovasi pembelajaran yang berorientasi soft skills. Makalan disajikan sebagai Makalah Pendamping dalam Seminar Nasional Pendidikan Teknologi dan Kejuruan Fakultas Teknik Universitas Negeri Surabaya tahun 2010. Surabaya: Unesa

Prabowo, Ardhi.2012.Pembelajaran Berbasis Proyek Untuk Meningkatkan Pemahaman Mahasiswa atas Permasalahn Statistika pada Perkuliahan Studi Kasus dan Seminar. Jurnal Kreano. Vol 3,(2)1-11

Resna Maulia Ayu Bernadi.2017.Peningkatan Kreativitas Siswa Kelas IV SD Melalui Pembelajaran Tematik Integratif dengan Pendekatan Open-Ended. Jurnal Prima Edukasia, 5 (1)91-101

Slameto. 2010. Belajar Dan Faktor-Faktor Yang Mempengaruhi (edisi revisi). Jakarta: Rineka Cipta.

Umi Faizah. 2015. Penerapan Pendekatan Saintifik Melalui Model Project Based Learning Untuk Meningkatkan Ketrampilan Proses Dan Hasil Belajar Siswa Kelas IV SD Negeri Seworan, Wonosegoro. Scholaria, Vol. 5, (1)24-38

Warsono, \& Hariyanto.2012.Pembelajaran Aktif Teori dan Asesmen. Bandung: PT Remaja Rosdakarya. 